\title{
The seismicity of Iran. The Kaj Darakht, Khurasan, earthquake of 25th May, 1923
}

\author{
N. N. Ambraseys (*) - A. A. Moinfar (**) \\ Received on April 21 st, 1977.
}

\begin{abstract}
SUmmarY - The Kaj Darakht earthquake of 25th May 1923 had a magnitude of 5.8 and occurred in a densely populated area of Khurasan, near Turbat-i Haidariyyeh. It affected an arcal of about 60 square kilometres and caused the death of about 900 people. The earthquake was felt within a radius of 130 kilometres and its epicentre is located on the Doruneh fault-zone. Originally calculated and recently re-calculated positions of its epicentre place the event 250 to 530 kilometres from its actual location. A re-examination of this event demonstrates the need for a critical study of early and more recent instrumental locations of events in regions of poor coverage from the world seismological network.
\end{abstract}

Riassunto - Il terremoto del 25 Maggio 1923, di magnitudo 5.8, avvenne in un'area del Khurasan densamente popolata, vicino a Turbat-i Haidariyyeh, ed interessò un'area di circa $60 \mathrm{~km}$ causando la morte di circa 900 persone. Il terremoto fu sentito entro un raggio di $150 \mathrm{~km}$ ed il suo epicentro localizzato nella zona di faglia di Doruneh. L'epicentro originariamente calcolato, e recentemente ricalcolato, è stato posto fra 230 e $530 \mathrm{~km}$ dalla localizzazione attuale.

Un nuovo esame di tale evento dimostra la necessità, per uno studio critico, di collocazioni strumentali di eventi passati e più recenti in regioni del mondo carenti d'informazione proprio per la loro lontananza da reti sismiche.

\section{INTRODUCTION.}

On the 25th May 1925 the region of Turbat-i Haidaryyeh in Khurasan (Iran) was shaken by a damaging earthquake. The shock,

(*) Imperial College of Science \& Technology, London.

(*⿻) Plan \& Budget Organisation, Tehran. 
which occurred at about two o' clock local time in the morning of the 5th Jauza (L th Khurdad 1302 shamsi, or 10th Shawwal 1341 hijri) affected Kaj Darakht and the Pain Vilayet of Turbat, which is situated about 10 kilometres southwest of the town of Turbat-i Haidariyyeh in a fertile plain which runs along the south foothills of Kuh-i Surkh, Figures 1 and 2. The earthquake destroyed a number of villages killing about 900 people, not far from where an earthquake caused heavy damage in $1903\left(^{2}\right)$.

The area encompassing the epicentral region of the 1923 earthquake is part of an active zone of seismicity which runs from north of Nishapur, along the north-south junction between the Lut Block and the Flysch Zone of Quhistan to Sistan. At Kaj Darakint this zone intersects the eastern part of the Doruneh fault, a major tectonic lineament which runs for over 600 kilometres from near Khwaf in the east to the central part of Dasht-i Kavir in the west. Historically, the region has been subjected to frequent earthquakes of moderate intensity and to infrequent large shocks. The largest events in this region occurred in 1336 and 1619. The former devasted the area between Sanjan and Khwaf killing about 20,000 people and the latter completely destroyed Dughabad $\left(^{3}\right)$.

The Kaj Darakht earthouake of 1923.

The earthquake was recorded by 39 seismological stations up to distances of 128 degrees. Of these stations, $76 \%$ were in the north-west quadrant, $14 \%$ in the north-east, and $10 \%$ in the south-east. The epicentres calculated by various agencies are listed in Table 1. The surface wave magnitude of $5.8 \pm 0.25$ was computed from horizontal component amplitude-period readings obtained from a number of European stations.

For the effects of the earthquake we are fortunate in having contemporary accounts of British consular agents in Khurasan and of the American Mission in Mashad (F. O. 371/9035, 10153 and 13059) as well as local correspondence of Persian officials. In addition, field studies in 1962 in connection with the small shock of 5 th October $\left.1962{ }^{(}\right)$and in 1975 have made it possible to reconstruct the effects of the cvent. 
The earthquake totally destroyed the village of Kuzan (also known as Tuzan and pronounced locally Ghujan or Ghuju), Figures 1 and 2 . It had a population of about 350 inhabitants and those who happened to be away survived. Most of the domestic animals in the village were also killed. The three qanats that supply the village with water were not damaged, but their yield decreased permanently. They did supply enough water, however, to encourage the gradual reconstruction of the village over a period of years, with some assistance from the American Church Mission in Mashad. Today, Kuzan is a prosperous settlement of about 400 inhabitants which has sprung up alongside the ruins of the old site.

About two kilometres to the west of Kuzan, the deserted village of Qalantarabad was totally destroyed, including a number of wellbuilt stone masonry domes. At the time of the earthquake this settlement was uninhabited as it was only used occasionally by those herding animals. Earthquake shaking was strong enough to cause the collapse of many ruined houses and slumping of the ground near the banks of erosion channels.

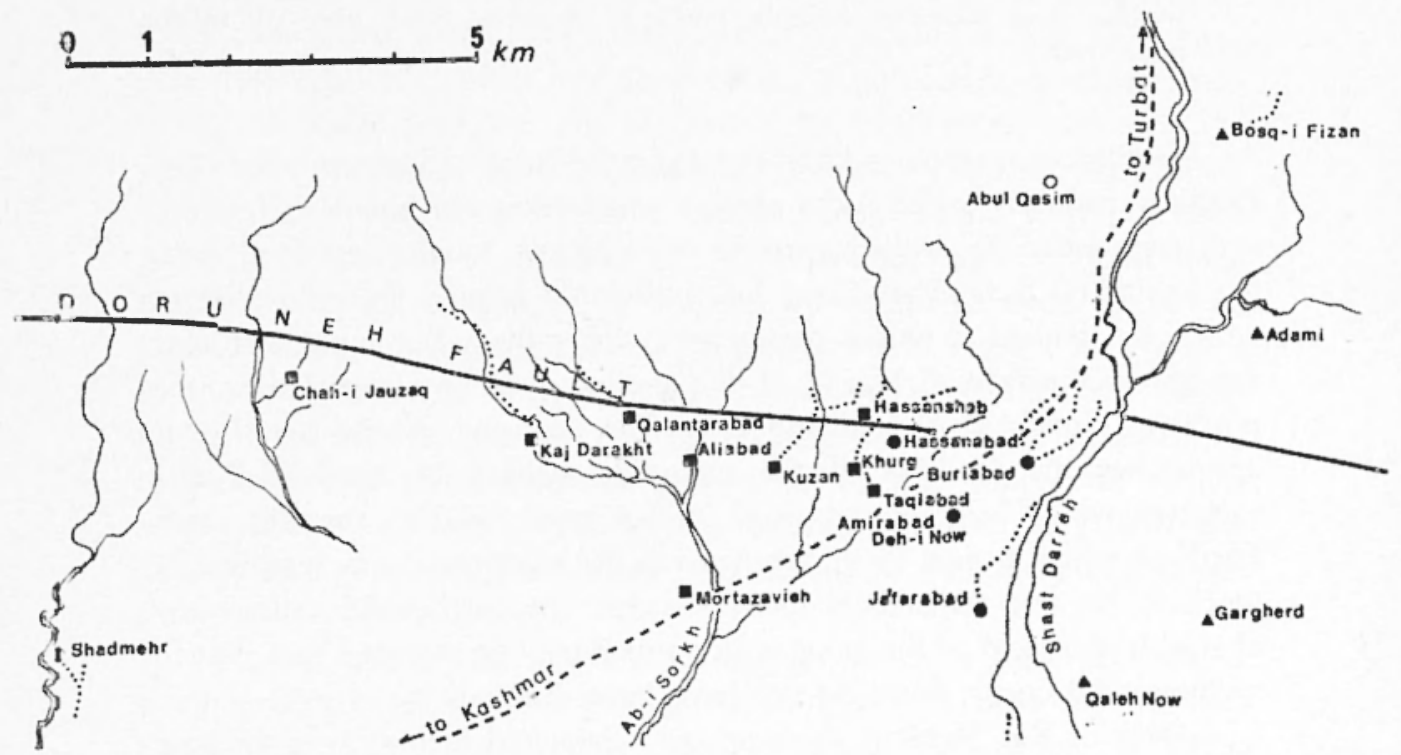

Fig. I - Location map of meizoseismal area of the carthquake of $25 \mathrm{th}$ May 1923. For regional location of the event, see Figure 1 in Ref. (2), Solid squares indicated villages almost totally destroyed with casualties: circles show locations of major damage and triangles, sites scriously damaged. Small dots indicate alignment of major qanats. 


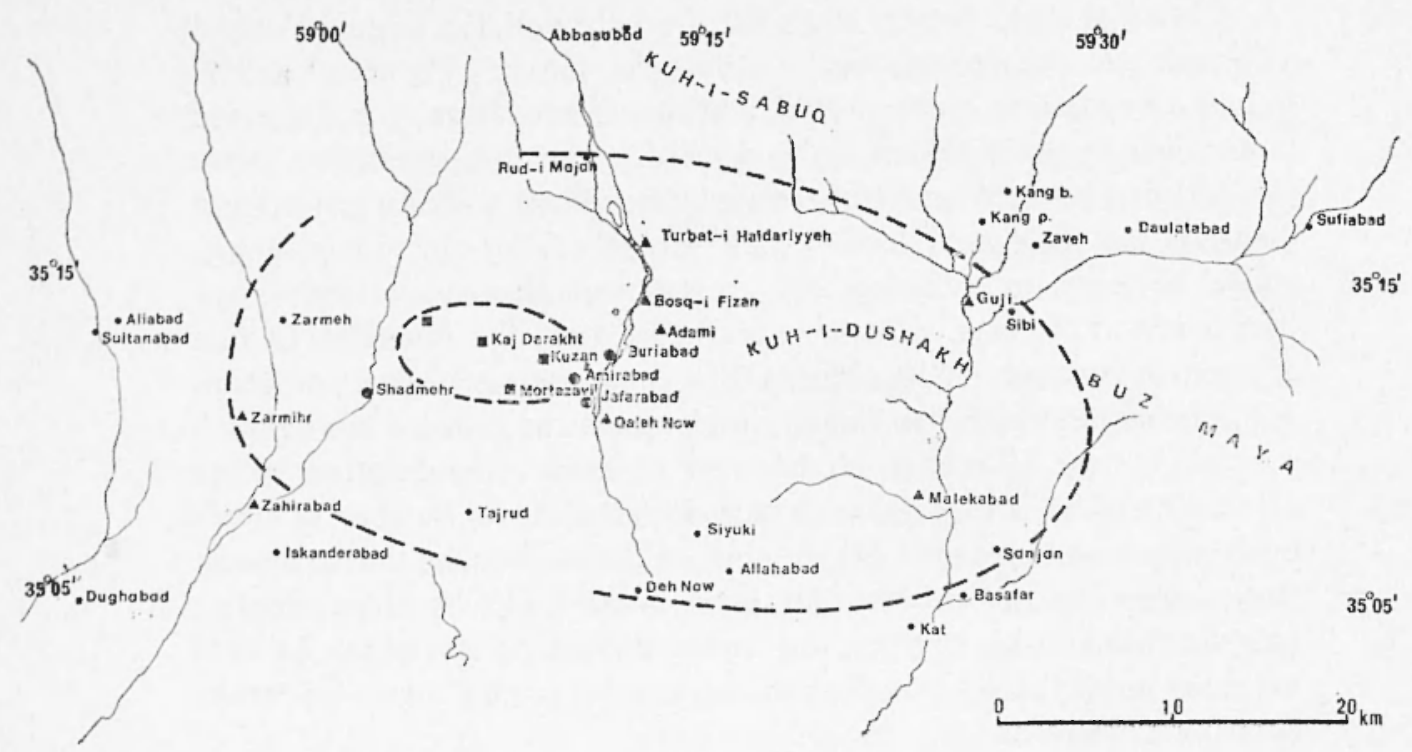

Fig. 2 - Location map of epicentral arca of the Kaj Darakht carthquake of 1923.

Dashed lines inclicates roughly limits of intensity VIII and VI (MM) respectively.

Further west, about a kilometre from the ruins of Qalantarabad, Kaj Darakht, formerly called Akbarabad, a small village of about 34 families and surrounded by walled gardens, was almost totally destroyed with the loss of 60 lives. The village was built on a heavily eroded pediment which was caused to slump particularly where the water table was near the ground surface. Cracking of the ground was also reported in the northwest limits of the village along the segment of the qanat that approaches the foothills of the mountain behind it. Landslides and rockfalls were also reported from further north of Kaj Darakht, as a result of which a pass to the north over the mountains was temporarily blocked. No one remembers today whether the earthquake caused any change in the yicld of the qanat water and it may be assumed that if such a change did occur, it would not have been dramatic.

West of Kaj Darakht there are no other settlements for a distance of at least eight kilometres. About three kilometres west-northwest of that place an isolated farm with a water well, Chah-i Jauzaq, was totally destroyed and the few people who lived there were killed. The site was abandoned after the earthquake. 
About one kilometre east of Kuzan, the village of Khurg or Khuraq was totally destroyed and half of its 220 inhabitants were killed. As a result of the earthquake, one of the two qanats of the village was completely blocked up and the other was seriously damaged; repairs took a long time and although eventually both qanats were put back into service, no one remembers today whether their flow had changed as a result of the earthquake. The village was rebuilt immediately after the event on a new site, a few hundred metres from the old and without any outside assistance.

Just south of Khurg, the village of Taqiabad was almost totally destroyed and ha'f of its 120 inhabitants were killed. A single qanat line was blocked and inspite of repeated attempts to repair it, its yicld continued to decrease until it dried up completely some years ago. The village was then abandoned and rebuilt a little to the north of its old site. In 1964 it was abandoned again because of lack of water and today it is totally deserted, the new Turbat-Kashmar road cutting right through the middle of its ruins. Survivors of the 1923 earthquake emigrated to near-by villages.

Mortazavieh (pronounced Murtazviyyeh) is the old site of Sadrabad. today called Hoz Sorkh. The village, which is located on the right bank of a deep erosion channet just north of the main road to Kashmar, was tctally destroyed and 180 out of 300 of its inhabitants, including the well-known muitahid, Sadr ul-Ulama and his seven children were killed. The snock was so violent that it caused much of the water in open ponds to be thrown out, and ruined the solidly-built vaults made of stone masonry covering ab-ambars. It also caused cracks to open up in the ground which run discontinuously for many tens of metres, mostly in a north-south direction, forming steps of about 30 centimetres throw towards the erosion channel that runs along the northeast outskirts of the village. The shock blocked the two qanats that supply the village with water, which began to flow at a reduced rate after they had been cleaned and repaired. The village was rebuilt to the north of the old site.

To the east of Hoz Sorkh, along the banks of Shast Darreh, a number of villages were heavily damaged but with little loss of life. Qaleh Now was a fortified settlement of about 170 people in 1923, situated on the left bank of the Shast Darreh, surrounded with a wall and corner towers. The earthquake destroyed four houses and ruined eighteen more, causing some damage to the walls and killing eight 
pcople. In the years following the earthquake the village was gradually abandoned and rebuilt outside and to the northwest of its walls. Some of the old buildings, such as the under-ground bath and storage cellars of the old settlement are still in use, the rest of the ruins are gradually disappearing, fig. 3 .

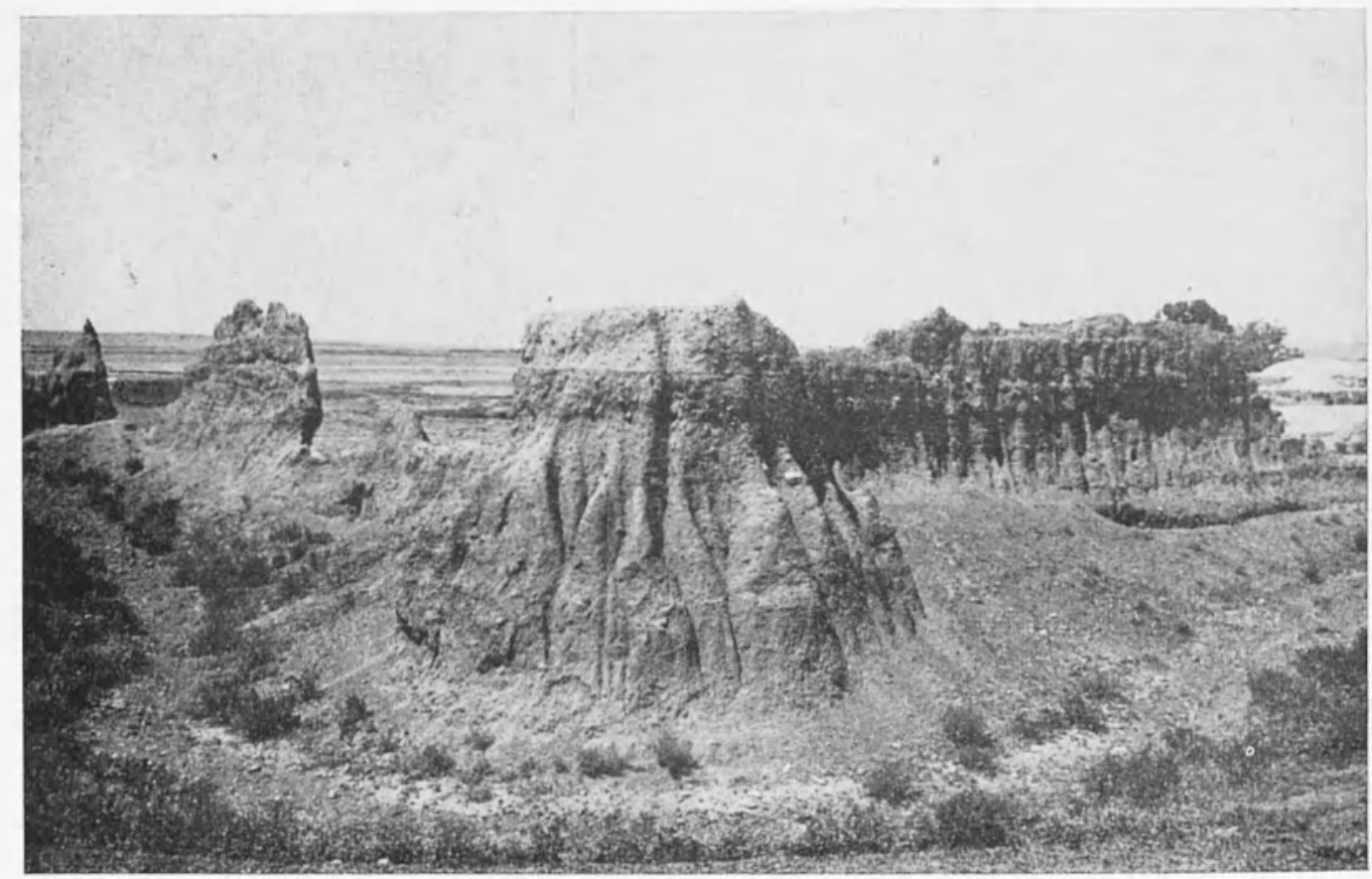

Fig. 3 - Ruins of wall of old site of Qal'eh Now.

Jafarabad, a village on the right bank of Shast Darreh, was badly shaken and although only scven houses collapsed completely (killing six people) the remaining sixty-two houses were so seriously damaged that they were abandoned and a ncw village was built next to the ruins of the old one.

Amirabad, formerly part of Deh Now, suffered considerable damage and half of its 35 houses were ruined with casualties. Together with near-by settlements of the Deh Now area, the earthquake killed twentyfour people. Most of the damaged houses were pulled down and rebuilt on the same sites. 
Further north, Buriabad was also damaged. Out of 500 inhabitants 15 were killed and 50 of its 120 houses were ruined. Although some of the service buildings of the Imamzadeh Sultan Ahmad Reza were damaged, the green-domed shrine of Ahmad Reza suffered no damage. There is some evidence that the yield of the qanats increased after the earthquake.

Adami was a large settlement with a population of about 400 . It suffered widespread damage and a few houses in the village collapsed but without casualties. At a distance of abou! two kilometres to the south of Adami it is alleged that the shock caused rockfalls and also cracks in the ground. These features are now no longer visible.

Beiween Adami and Turbat-i Haidariyyeh, at Bosq-i Fizan (or Bislifzan) a few hcuses were ruined injuring a number of people. No house collapsed completely but half of the 130 dwellings in the village were clamaged beyond repair.

Ncar Buriabad the small settlement of Qal'en Yazdikha was almost tctally destroyed and a few people were killed. On the other side of Shast Darreh the few houses around the shrine of Sheikh Abu'l Qasim were damaged, but the shrine itself sustained no damage.

In 1923 Turbat-i Haidariyyeh had a population of 10,000 and of its 1460 houses 230 were damaged, mainly with cracks in the walls and dislodged roof-beams and corner walls. Not more than 25 poorlybuilt houses, chiefly made of adobe, were entirely dsetroyed killing 7 to 8 people and a few animals. Many high garden walls collapsed blccking the narrcw streets, and some parapets fell off from houses. The bazaar, built in 1860 ( $\left.^{11}\right)$ of burnt brick with good roofs, containing more than 200 shops, suffered practically no damage except for a few cracks and the collapse of a roof in one of the old shops. The shrine of Qutb-ad-Din Haidar, a massive brick structure bearing an inscription with the date 1021 hijri, i. e. 1612 suffered absolutely no damage. Also, the adjacent large jame which bears an inscription dated 1040 hijri, i. e. 1630, suffered only a long vertical crack through the brickwork of the left wing of its ivan which is still visible and which was attributed to the effects of the 1968 earthquake at Dasht-i Bayaz, Fig. 4. As a result of the earthquake, four yanat lines connecting the town and the villages of the Turbat area were blocked, and about 20 people were killed in outlying settlements of the Bala Vilayet. 


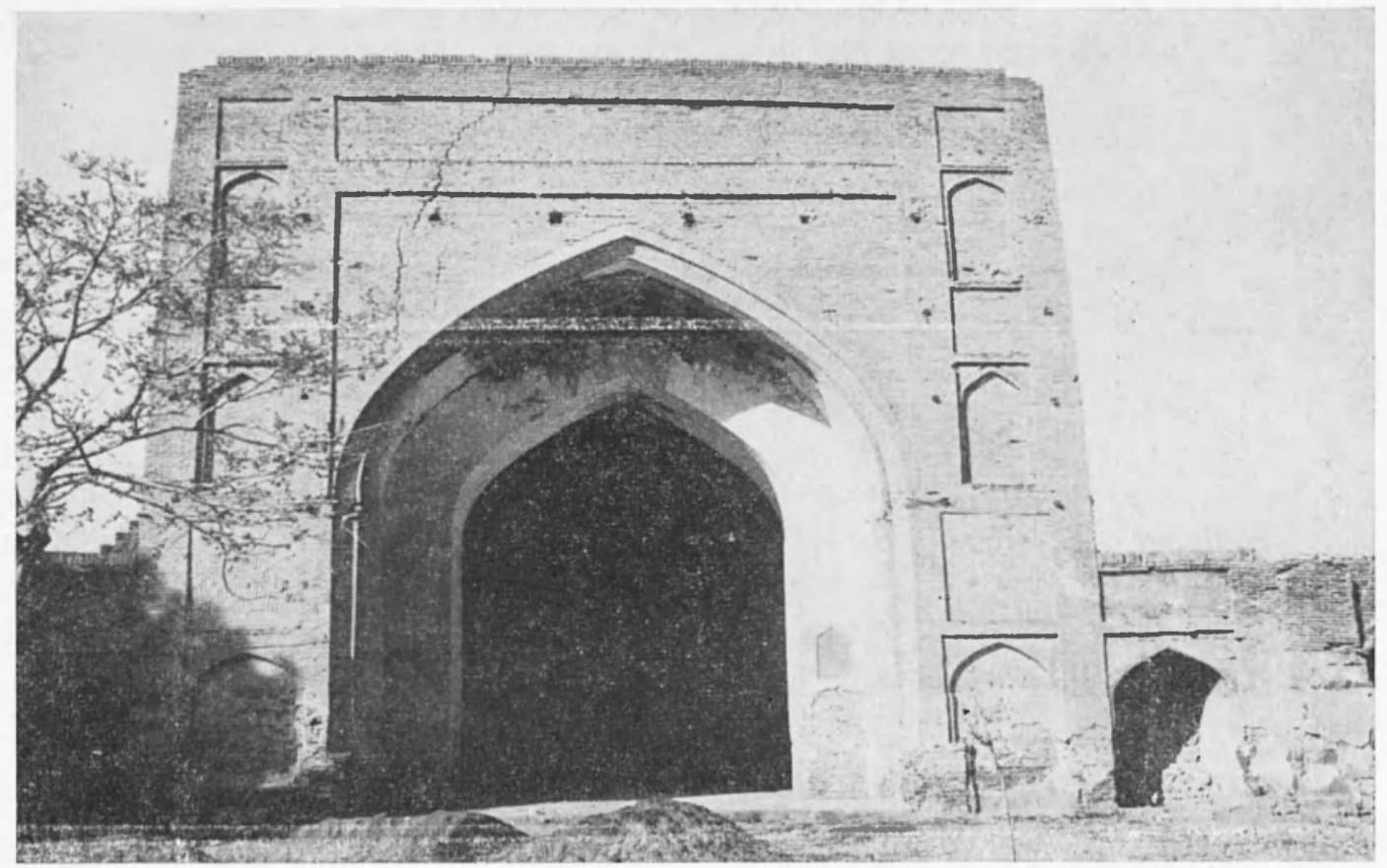

Fig. 4 - Damaged ivan of the jame of Turbat-i Haidariyyeh.

East of Turbat-i Haidariyyeh damage was widespread but minor, with the occasional collapse of a few adobe houses. Damage extended for almost 20 kilometres east of the town. At Guji (also pronounced Kuchu) a few houses collapsed completely killing four people on the outskirts of the village.

The slopes and foothills of Kuh-i Dushakh are sparcely populated and provided no evidence of damage. Only for Malekabad (also know as Maliki, not to be confused with Mulkabad of the Bala Vilayet which is situated about eight kilometres northeast of the town) there is evidence that a few houses were damaged and one collapsed killing three people.

Shadmehr (also Shadmeh or Sharid) in 1923 was a large village on the old road from Turbat to Kashmar, with a population of about 700 people. It was built on the right bank of Ab-i Shadir and part of the scttlement was surrounded with a wall. The earthquake destroyed a few houses killing 15 people and damaged about 50 dwellings 
almost beyond repair. After the earthquake the village was gradually abandoned, and a new village of the same name appeared 2.3 kilometres to the scuth of the old site, cal'ed Bala Qaleh today, on the north side of the new road to Kashmar, fig. 5.

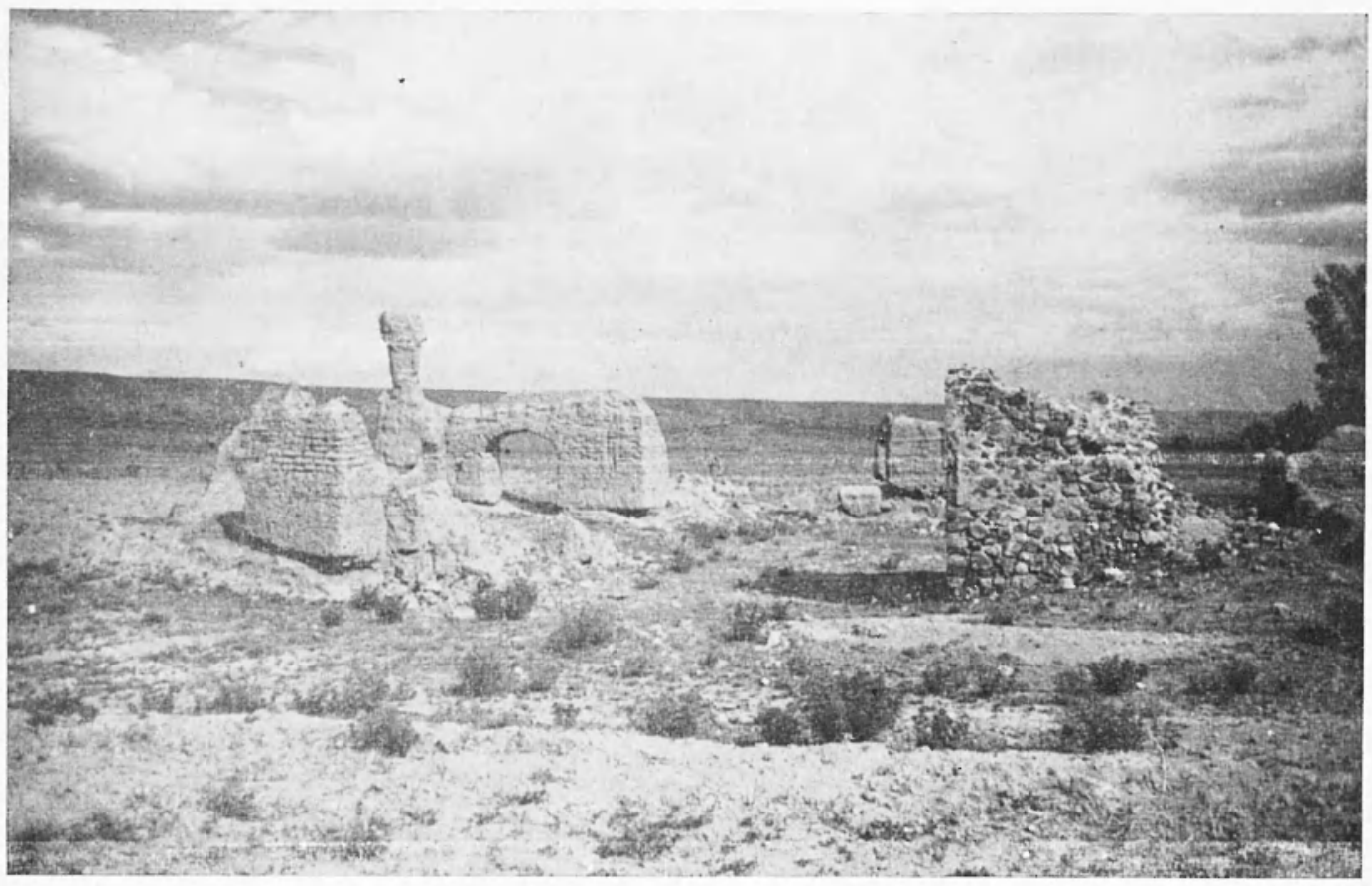

Fig. 5 - Ruins of abandoned village of Shadmehr.

At Zahirabad (or Ziabad) and in Zarmihr the shocks damaged a few houses and destroyed free-standing garden walls. The earthquake was strongly felt without damage at Aliabad, Sultanabad and Sarmeh. At Iskanderabad also, there was no damage except for a few walls that cracked. It is said that a qanat which was dry before the earthquake started to flow again after the event. There was some slight damage at Tajrud, Deh Now and Siyuki (Siuli or Siki) and a few adobe houses ccllapsed without casualties. It is not clear whether Allahabad suffered any damage. Some reports claim that none of the 50 houses of the village suffered any damaged while others suggest that here as wcll as at Siyuki damage was serious and that a few people were also killed. 
At Kat, Basafar (or Basfur), Kang Bala, Kang Pa'in, Daulatabad and Sufiabad the shock was very strongly felt, causing panic but no damage. Further away from the epicentral area at Burjiabad (or Burj), abcut 40 kilometres north-northwest of Kuzan, the shock was strong enough to awake people. It was also felt at Robat-i Sefid, 72 kilometres north-northeast of the epicentral area. In Mashad, 130 kilometres away, the earthquake was almost imperceptible and would probably have passed unnoticed had the damage at Turbat-i Haidariyyeh not drawn attention to it.

The earthquake of 1923 was preceded and followed by a number of damaging shocks:

1923 Mar. 6 At about $1100 \mathrm{pm}$. local time a strong shock caused panic at Abbasabad destroying two houses.

May 28 Strongly felt in Turbat at $7.30 \mathrm{am}$. (GMT).

June 1 Felt in Turbat, followed by numerous minor shocks.

June 2 Felt throughout the Vilayet of Turbat.

June 11 At 1030 local time, severe shock caused some damage, followed by an equally strong aftershock at $3.30 \mathrm{pm}$.

June 14 At about $6.00 \mathrm{am}$. violent aftershock causing additional damage; fo!lowed at $4.00 \mathrm{pm}$. by another, stronger shock.

June 18 Continuing aftershocks of decreasing intensity; damage caused by the main shock was aggravated by heavy rains.

Aug. 15 At about $8.00 \mathrm{am}$. strong shocks caused panic in Turbat.

The seismic activity in the Turbat-i Haidariyyeh region was concluded by a shock on the 14th November which caused damage at Abbasabad, where a few houses were ruined and one person and a few animals were killed.

\section{Discussion.}

The earthquake of the 25th May 1923 had a relatively small magnitude of $M_{s}=5.8$, but it happened to occur in the densely populated area of Kaj Darakht where it destroyed a number of villages killing 
about 900 people. The radius of the devastated area, Figure 2, hardly exceeds five kilometres and the damage and casualties caused in the town of Turbat-i Haidariyyeh were in fact relatively small. The damage in the town which was an important communication centre in Khurasan, was, however, grossly exaggerater and this excited widespread interest and concern.

News of the earthquake was sent out by telegraph from Turbat to Tehran and it reached the outside world almost immediately. Reports in the European press of the period 27th to 31 st May, originating from the Mashad correspondent of the "Pioneer of Allahabad" (The Times, 28th May - 5th June 1923) and in the Persian press (Shafaq-i Surkh, 27th Khordad - 10th Shahrivar 1302) which gave a rather exaggerated description of the damage wrought by the earthquake, have until recently been the only sources of information for later accounts of the event. They refer to the complete destruction of Turbat-i Haidariyyeh and of many of its village with a loss of 3000 to 4000 lives. In the Bulletin of the Seismological Society of America (13, pp. 80-81) we find an extraordinarily muddled account of the earthquake, which is dated the 6th May, and in which the entire region of Turbat-i Haidariyyeh was said to have been destroyed with the loss of 1000 lives. The account adds that continuing aftershocks, particularly in the week preceding the 17 th June 1923, destroyed eight villages killing 3000 people. Another version of the disaster. equally incorrect, is given by Sieberg $\left({ }^{10}\right)$ who dates the event on the 26th May and adds that the earthquake destroyed 30 villages within a radius of 25 kilometres, killing 300 people. Rustanovich $\left({ }^{9}\right)$ assigns an intensity of IX to the earthquake, on the authority of Sieberg's account.

Unpublished records of the earthquake, both British and Persian, are remarkably full of detailed information about the event and its aftermath, so that supplemented with information obtained in the field by the authors and by Dr. Tchalenko $\left({ }^{12}\right)$, they afford a reasonably faithful reconstruction of the situation created by the 1923 earthquake.

An official contemporary account of the earthquake, issuing from local sources, is given by Bahar $\left.{ }^{7}\right)$. It consists of transcripts of reports sent immediately after the earthquake from Turbat to Tehran, and the language is reminiscent of contemporary newspaper reports, which are often over-eager to exaggerate. The following is an extract of the various reports referred to by Bahar:

"All the weakly" built houses (in Turbat-i Haidariyyeh) are entirely 
destroyed ... The telegraph operator of Turbat, who has only got one instrument which is located in a tent, is working extremely hard to keep the lines of communication open ... What up till now has been heard in the town is that nearly 35 people were killed... The important villages of Jauzaq and Sadrabad were shaken down and a small number of the large population escaped half alive. The Sadr al-Ulama with his son-in-law and 6 children and his dependents, who were in Sadrabad, perished $(5$ th Jauza)... The verified number of casualties apart from those wounded, which are at present ascertained are as follows: Malaki 3 killed; Gauju 4; Bala Vilayet 20; Murtazviyyeh 400; Tuzan 900; Khuraq 500; Ja' farabad 24; the total of the rest of the villages and of the town is altogether 2,219 (7th Jauza)... The number of the dead and wounded of the town are 60 people. In the destroyed villages of the area ... Khuraq, Tuzan, Kaj Darakht, Taqi Abad. Dehnau and Maratsuyeh, there were a small number who were not in these places; the rest who were in excess of about 2000 people, were all buried beneath the destruction. In various other villages up to one and a half Farsakhs away, more than 600 people died. As is supposed, and stated in the most recent estimate, the deaths are nearly 3000 ".

In contrast, the diaries of the Consul-General in Mashad, reflect a somewhat different picture of the situation. The entry for the day after the earthquake says that:

"The first shock was followed by others until by the evening some 20 had been noted. Reports are incomplete but it appears to be wellestablished that in Turbat-i Haidariyyeh iiself some 500 houses have been destroyed and about 40 people killed. 30 villages within 14 miles of Turbat were also severely afjected".

The diaries for the week ending 2 nd June give a list of 31 villages that were affected, adding that:

"The shocks were severe in the pillages of Murtazviyyeh, Kuzan, Khurq, Taqiabad and Kaj Darakht, which are included in an area of 6 square miles, situated about 10 miles southwest of Turbat ».

The report adds that the official figures of casualties up to $31 \mathrm{st}$ May given by the Governor General and Karguzar are 2.219 killed and 170 injured, of which 30 need hospital treatment. The report then mentions measures for relief. Three ccmmittees were established, one for caring for the injured, feeding the hungry and burying the dead; one for the cultivation and irrigation of the victims' crops; and one for administering claims on the wills and property of the dead. 
However, a subsequent visit and report by Dr. Litchwardt of the American Mission in Mashad shows that these original reports were exaggerated; there was little damage in Turbat, a fact ascertained by the authors in 1962 and 1975 and by Dr. Tchalenko $\left({ }^{12}\right)$, and only 30 people were killed. Only five villages were completely destroyed and 20 partly damaged with no more than 1000 killed. The report puts the total damage at 100,000 to 150,000 tumans.

The Mashad diaries for the 9th June 1923 mention that the Governor-General recommended a grant of 100,000 tumans from the Tehran treasury for the rebuilding of houses before the oncoming winter. This petition was discussed in a public session of the Majlis and the speech delivered on the occasion by the Shah, on the 20th Khurdad, is given by Bahar $\left({ }^{7}\right)$.

The diares reflect the local feeling that relief funds if granted would presumably be spent entirely on Turbat-i Haidariyyeh and that the destroyed villages would never be rebuilt. The view was that there was little need for a relief fund for the villagers, as the survivors inheriting the estates of their deceased relatives would be better of than they were before. In fact, this is exactly what happened. The Mashad Consular daries for April 1928 say that:

"The balance of the funds collected for the relief of sufferers in the earthquake which occurred in Turbat-i Haidariyyeh four years ago has been devoted to the construction of a hospital at that place which is now nearly completed".

Taking all available written evidence in conjunction with field observations and interviews with survivors of the earthquake it may be concluded that the meizoseismal area of the $192 j$ earthquake was small, hardly exceeding 60 square kilometres, with a macroseismic epicentre at $35.21^{\circ} \mathrm{N}-59.12^{0} \mathrm{E}$, near Kaj Darakht, and about one kilometre south of the most prominent fault trace of the Doruneh zone. Within this area the intensity of shaking must have reached VIII (MM) as people and animals were thrown to the ground and stone masonry domes resting on the ground were destroyed. This area encompasses the existing villages of Kaj Darakht, Kuzan, Khurgh and Mortazavieh as well as the deserted sites of Chah-i Jauzaq, Qalantarabad, Aliabad, Taqiabad, Hassanabad and Hassanshab and a number of farms, in which about 770 people were killed. Ground deformations were in all cases local, mainly due to slumping of the ground near erosion channels and old qanats. There is no evidence that any of these features are of 
tectonic origin, nor is there any evidence of movement on the most prominent fault traces of the Doruneh zone. The effect of the earthquake on the flow of the qanat water supply was not significant $\left({ }^{12}\right)$. Only one major qanat line was damaged beyond repair; in almost all others flow of water eventually came back to normal.

The damaging effects of the earthquake outside the meizoseismal region extended within an area of about 1000 square kilometres where, in all, 90 peop'e were killed, Figure 2. Within this area, which extended mainly to the east from the epicentre, the most frequently occurring intensity should not have exceeded VI (MM). The consensus of opinion and testimony for the damage in Turbat-i Haidariyyen itself is that apart from 20 to 30 old houses and many high garden walls that collapsed killing eight people, there was no destruction of better-built houses. The total number of deaths in the tcwn and in its suburbs of Bala Vilayet was about 20, which is consistent with the report of Setar-i Qutb. Indeed, damage in Turbat had been grossly exaggerated.

\section{Conclusions.}

The Kaj Darakht earthquake of 1923 was a relatively small event as compared with other earthquakes in I ran. It did cause a heavy loss of life because it happened to strike a densely populated area and it did attract widespread interest because of its proximity to one of the most important communication centres of eastern Persia.

Its particular interest lies in the fact that it is the only seismic event of this century that happened to occur so near the Doruneh fault zone. However, neither the magnitude of the event nor the historical and more recent seismicity of this zone are consistent with such a major tectonic element which seems to remain strangely quiescent.

The re-examination of this earthquake on the basis of historical sources of information and of field studies has made it possible to locate the event more accurately by supplementing the meagre instrumental data available. From Table 1 we notice errors in the instrumental location of its epicentre of 407 kilometres, for the calculations made by ISS $\left(^{6}\right)$, which places the earthquake in the Dasht-i Lut; of 226 kilometres, for the recent re-calculations carried out by the IGS $\left(^{5}\right)$, which places the epicentre near Herat in Afghanistan; and of 524 
kilometres for the adopted epicentre by Strasbourg $\left({ }^{8}\right)$, which locates the event in Baluchistan. As a matter of fact. a recent study of the seismic zoning of the Turbat region, based on ISS epicentral locations, does not include this event $\left({ }^{4}\right)$. The re-examination of the Kaj Darakht earthquake demonstrates the need for relocating early and more recent events on the basis of historical and field evidence.

TABLE 1

Characteristics of the Kaj Darakht earthquake of 25 th May 1923

\begin{tabular}{|c|c|c|c|c|c|c|c|}
\hline Origin & \multicolumn{4}{|c|}{ Epicenter } & \multicolumn{3}{|c|}{ Location } \\
\hline \multirow{2}{*}{$\begin{array}{l}\text { Time } \\
\text { (GMT) }\end{array}$} & \multicolumn{2}{|c|}{ Instrumental } & \multicolumn{2}{|c|}{ Macroseismic } & \multirow{2}{*}{$\begin{array}{l}\text { Magnitude } \\
\qquad\left(M_{s}\right)\end{array}$} & \multirow{2}{*}{$\begin{array}{l}\text { Error } \\
(\mathrm{km})\end{array}$} & \multirow[t]{2}{*}{ Source } \\
\hline & $\mathrm{N}$ & $\mathrm{E}$ & $\mathrm{N}$ & $\mathrm{E}$ & & & \\
\hline 22125 & $32.0^{\circ}$ & $-57.0^{\circ}$ & & - & & 407 & (6) \\
\hline 22132 & 34.63 & $3-61.49$ & & & & 226 & (5) \\
\hline \multirow[t]{2}{*}{2221} & 31.5 & -62.6 & & & 5.6 & 524 & (8) \\
\hline & & - & 35.2 & $-59.12^{0}$ & 5.8 & 一 & This study \\
\hline
\end{tabular}

Note: $r_{3}=135 \mathrm{~km} ; r_{4}=72 \mathrm{~km} ; r_{5}=40 \mathrm{~km} ; r_{6}=18 \mathrm{~km} ;$ and $r_{0}=4.5 \mathrm{~km}$.

$\left(\mathrm{I}_{0}=\mathrm{VIII}\right)$

ACKNOW LEDGEMENTS.

The authors would like to record their indebtedness for the help they have received in 1962 from the late Prof. S. Abdalian in retrieving many of the documents referring to this event, and for guidance in interpreting the results. They would like to thank Mr. C. Melville for collecting additional data from the Foreign Office and for reading the manuscript.

The field work was supported by the Natural Environment Research Council, London and the Plan \& Budget Organisation, Tehran. 


\section{BIBLIOGRAFIA}

(1) Ambraseys N., 1963. - The Buyin-Zara earthquake of September 1962. Bull. Seism. Soc. Amer., 53, p. 737.

(2) Ambraseys N., Moinfar A. A., 1975. - The seismicity of Iran; the Turshiz (Kashmar) Khorassan earthquake of 25 th september 1903. Annali di Geofisica, 28, pp. 253-69.

(3) Ambraseys N., Melville C., 1977. - The seismicity of Quhistan, Iran. The Geographical Journal, 143, pp. 179-199.

(4) Goudarzi M. K., Javaheri J. H., 1974. Seismic zoning of Eshghabad and Torbat-i-Haidari. Journal Earth and Space Physics, 3, N. 2, p. 10, Tehran.

(5) Institute of Geological Sciences, Earthquake Files. Edinburg.

(6) International Seismological Summary. Kew.

(7) Malik Ash-ShUara' Bahar, 1944. - Tarikh-i-mukhtasar-i ahzab siyasi-ye inqiraz-i Qajariyyeh. Tehran 1323 shamsi, pp. 328-330.

(8) Rothe E., 1924. - Annuaire de l'Institut de Physique du Globe 1923. Bull. Burcau Central Seism. Français, p. 17.

$\left({ }^{9}\right)$ Rustanovich D. N., 1967. - Seismichnost territorii Turkmenskoi CCP $i$ Ashkabadskoe zemletrasenie 1948. Vapros. Inst. Seism., 12, p. 15, Izdat. Nauka.

(10) Sieberc A., 1932. - Die Erdbeben. in B. Gutenberg's Handbuch der Geophysik, 4. p. 815.

(11) Smith E., 1876. - Eastern Persia, an account of the journeys of the Persian boundary commission 1870-1872. MacMillan, 1, p. 353.

(12) TChalenko J., 1973. - The Kashmar-Turshiz 1903 and Torbat-e HaidariyehSouth 1923 earthquakes in Central Khorassan, Iran. Annali di Geofisica, 26. pp. $29-40$. 